\title{
Cultural Relativism and Feminist Discourse in Sharat Chandra Chattopadhyay's Fiction vis-á-vis his Concepts on the 'Worth of Women'
}

\author{
Dr. Madhumita Purkayastha \\ Associate Professor \& Head, Department of English, D.H.S.K. College, P.O. Dibrugarh, Assam, India.
}

\begin{abstract}
The theory of Cultural Relativism in Comparative Literature entails cross-cultural literary investigations, which are based on an understanding that calls for an 'empathetic' appreciation of the functions that a culture performs in society. Thus, instead of merely comparing one text with another, literary comparisons like relativism explore the functions a text performs in the respective system in terms of the cultural values represented by it. According to noted Indian feminist Maya Pandit, women's issues have formed an important part of the agenda of political and cultural movements in India right from the colonial days. A feminist reading of portrayals of Indumati and Achala in Sharat Chandra Chattopadhyay's Darpachurna and Grihadaha respectively would also incorporate the methodology of Cultural Relativism in the colonial context. The present study proposes to examine Sharat Chandra Chattopadhyay's essay "Narir Mulya" that encapsulates his views on cultural transpositions of "modern" and "liberal" western ideologies and concepts of women's issues in the Indian socio-cultural context vis-à-vis his fictional representation of "educated", "liberal" middle-class Bengali women epitomizing his brand of "feudal feminism" as found in his short story "Darpachurna" and his novel Grihadaha.
\end{abstract}

Key words: Cultural relativism, feminist discourse, colonial context, feudal feminism.

\section{Introduction}

Cultural Relativism as one of the theoretical premises of Comparative Literature has enriched textual reading in view of the colonial context in India, a multilingual, multicultural, poly ethnic nation with a colonial past. Comparative Literature has opened up a vista of possible critical apertures and theoretical dimensions in the examination, enquiry, analyses, interpretation and understanding of texts in different languages through the ages in relation to the literature of the colonial masters and subsequently to the literatures of the "west". The theory of Cultural Relativism in Comparative Literature entails cross-cultural literary investigations ${ }^{1}$ which are based on an understanding that "calls for an 'empathetic' appreciation of the functions that a culture performs in society". ${ }^{2}$ Thus, instead of merely comparing one text with another, literary comparisons like relativism explore the functions a text performs in the respective system ${ }^{3}$ in terms of the cultural values represented by it i.e. a literary text as a repository of cultural values that are in turn influenced by exposure to 'other' cultures - their reception, rejection, impact or influence on indigenous cultures. The crux of Cultural Relativism at its best lies in empathy - best demonstrated by the native Indian intelligentsia who, "(s)trikingly enough, though fully aware of the colonial design, ... did ever feel grateful to the British for an exposure to modernity. They could forget the humiliations the yoke of subjugation had subjected them to. Taking these as instances of individual failings, they tried to rationalize the general tendencies as liberal." ${ }^{, 4}$ So Sharat Chandra Chattopadhyay, the doyen of Bengali fiction in the $19^{\text {th }}$ century, in his essay on "woman's worth"- "Narir Mulya" appeared to count the blessings of the British Raj in terms of women's emancipation in India through the imposition of bans on "Satidah" (burning of widows in the funeral pyre) or the Widow Remarriage Act that enabled social rehabilitation of widows. Yet in his fiction Sharat Chandra Chattopadhyay's middle class Bengali women protagonists who are "educated" and "liberated" according to the standards of the neo-western Bengali society, fail to consolidate or bring to fruition their feminist rebellion in positive denouements (debunking constrictive traditions and cultural stereotypes) befitting their daring and unconventional personalities.

Again, acknowledging the truth of Maya Pandit's statement that women's issues have formed an important part of the agenda of political and cultural movements in India right from the colonial days ${ }^{5}$ is not difficult when one examines texts (literary, socio-cultural and political) written in different regional languages in India. If "feminist criticism is a re-examination through creative literature of the role and status of women in our society and a new way of portraying woman as an individual and an exposition of themes of oppression, sense of outrage and also images of courage and determination in portrayals of women that serve as role models,${ }^{6}$ a feminist reading of portrayals of Indumati and Achala in Sharat Chandra Chattopadhyay's Darpachurna and Grihadaha respectively would also incorporate the methodology of Cultural Relativism in the 
colonial context. In Swapan Mazumdar's words, it would entail an attempt "to reveal, describe and assess the relative changes in rhythmic pace in life-style and its concomitant world view" 7 .

\section{Hypothesis}

The present study proposes to examine Sharat Chandra Chattopadhyay's essay "Narir Mulya" that encapsulates his views on cultural transpositions of "modern" and "liberal" western ideologies and concepts of women's issues in the Indian socio-cultural context vis-à-vis his fictional representation of "educated", "liberal" middle-class Bengali women epitomizing his brand of "feudal feminism" as found in his short story "Darpachurna" and his novel Grihadaha.

\section{Argument}

Despite the apparent enthusiasm regarding the legal impositions of women-friendly laws by the British Raj in India in his protracted discussion on the 'value' of woman in his "Narir Mulya", on close examination, Sharat Chandra Chattopadhyay's essay yields sufficient evidence of his skepticism regarding the issue of remarrying widows (as a cultural invasion as well as a pitfall perpetuating the vicious cycle of dependence and bondage), though his indictment of 'sati' and the unimaginable cruelties of widow burning is vehement enough. In a veritable tirade against patriarchy as the root cause of exploitation of women, Sharat Chandra Chattopadhyay in his essay "Narir Mulya" has quoted extensively from and alluded to sociological, political, cultural and religious tracts and treatises by a host of western (European) scholars, philosophers and theologists to give instances of western chauvinism that could put the so called "narrow, parochial, native" dogmas to shame. Such cross-cultural references not only evidenced his exposure to and acquaintance with Western (read colonial masters) culture but also recorded the Eastern reader's (read colonized subject) reaction/resistance to it while presenting an alternative world view.

Sharat Chandra Chattopadhyay has succinctly stated the Occident-Oriental debate regarding woman's "liberty" and "emancipation" in his essay. The cutting edge of his satire is directed both towards the western concepts (newly emerging) of women's emancipation from confining social codes and norms and the eastern argument of the virtues of such confinement as our culture and religion believed in enshrining women as goddesses on pedestals. Pointing out the inherent male selfishness in both the stances, Sharat Chandra exposes the commodification of women that has resulted in her oppression through the ages irrespective of East or West, everywhere in the world. While disagreeing with the European cultural systems and social codes regarding either women's liberty or the true appreciation of their values, he has also questioned Manu or Parashar's (ancient Hindu writers of scriptures) theory of worshipping women by eulogizing the virtues of her endurance, servitude, nurturing, and above all, chastity. In a cutting indictment of the patriarchal foundations of the social norms formulated only for subjugation of women and for conveniently serving the selfish interests of men, Sharat Chandra Chattopadhyay exposes the sham values and double standards of a society that set different codes of conduct for men and women and a culture that glorified sacrifice and chastity only on the part of women. Despite his attack on "Satidaha pratha" and his genuine appreciation of the British Raj's role in banishing it, Sharat Chandra Chattopadhyay is however sceptical regarding the western ideals of women's liberty. Scrutinizing the cultural codes and norms of a cross section of barbarian tribes of the world, Sharat Chandra has compared their primitive (and therefore perhaps more excusable in his opinion) chauvinism to the systemic and systematic institutionalized devaluation and degradation of women in the preaching and practices of the Christian Church. For Sharat Chandra, Christianity as a religion that enunciated the theory of the inception and creation of the world as an outcome of original mother Eve's sin and Adam's downfall, a religion that has held Eve as the root cause of all sins in the world and consequently been responsible for subjecting womankind to worst kinds of humiliation and indignities, could only pretend to understand the true worth of womanhood. Sharat Chandra's world view thus registers \& recognizes the existence of a worldwide discriminatory culture founded on a centuries long history of subjugation of women practiced by both European (western) and Indian (Eastern) civilizations. In his protracted discussions, Sharat Chandra Chattopadhyay deals with various aspects of womanhood, man-woman relationships, widowhood, widow remarriage and its social implications in India, monogamy versus polygamy, women's beauty, virtues and worth, women's education, motherhood and sexual division of labour and such other issues. By his own admission, his cross-cultural comparisons and sociological enquiry have been motivated by his belief that the moral progress of mankind is in no way more clearly shown than by contrasting the position of women among the savages with their position among the most civilized ${ }^{8}$. His socio-cultural and ethical concerns provide interesting pointers to his unconventional views about women's issues in the Indian context. In an interesting subversion/countering of accusations of chauvinism usually leveled at Islamic religion by patrons of Christianity and Hinduism, Sharat Chandra Chattopadhyay quotes instances of Mohammed's instructions to his followers in the Holy Quran to be fair to womankind. Linking the subjugation of women and social injustice to the regression of societies and cultures, Chattopadhyay condemns man's imagined rights over women while advocating "those higher 
sentiments accompanying union of the sexes, which do not exist among primitive men"--- for altruism and empathy with the "other half" of mankind."

Let us now examine Sharat Chandra Chattopadhyay's fictional representations of women vis-à-vis his concerns about women's problems and issues in society as exposited in his essay. Undeniably Sharat Chandra Chattopadhyay's novels and short stories are women centered. Most of his chief protagonists are female and the flow of narrative in most of his fictional work is determined by his woman characters or follows the destiny of his female protagonists. They are arguably more dynamic and unconventional than their male counterparts. The beauty and complexity of his works can be attributed mainly to his women characters ${ }^{10}$ Yet, it is not only due to his family centred plots or his interest in the exchanges of love or his admitted admiration of the "madhur rasha" (sweet taste, flavour, feeling- ref. Indian Rasa theory) of love and conjugal bliss that have been instrumental in his being one of those rare male writers who have been able to capture the essence of womanhood through his sensitive exploration and representations of women's psyche, their dilemma, their indignation at injustice, their oppression and consequent struggles against rigid social codes of conduct, their resistance to conventional mores and norms and emergence and emancipation from confining cultural systems through a reinforcing of their self-esteem. If these as such can be identified as feminist concerns or premises or feminist criticism, then Sharat Chandra's fiction is a rich storehouse of such issues in the Indian context, which in turn involves the comparative approach of rediscovering Indian womanhood through a relativistic understanding of neighbouring cultures. In the context of India during the colonial era, it would then necessitate the juxtaposition of cultural values in terms of the role and status of women in a society of colonized subjects reacting to or resisting influence or seeking integration /assimilation with the cultural values of the colonizers who could bring to bear upon the former their ideologies, critical canons, social norms and cultural systems through legal impositions as well as control over education and even creative expression (i.e. critical and literary texts).

To examine Sharat Chandra Chattopadhyay's "feminism" in the light of a national colonial experience as well as a testimony to his convictions borne out by the essay on woman's worth (as gauged by the world and India in particular), the study proposes to analyse two texts which can be considered to be critiques of that brand of radical feminism ${ }^{11}$, which Sharat Chandra Chattopadhyay identified with extreme western cultural anarchy (usrinkhalata/indiscipline). In Indumati of Darpachurna we find through literary representation a rejection (as in defeat) of that "masculine" pride or egotism (which in a woman is deemed intolerable-a stance reinforced by Bimala's advice to Indumati and Mrinal's counsel to Achala) the destructive powers of which are associated with a blasphemous disregard of the Indian God's will, the Indian society's better tenets and an undermining of the very edifice of the Indian culture of a woman's "sewa dharma" and unshakeable loyalty and fidelity to her husband - referred to as swami which literally means lord and owner/possessor. Indu's tirade against the "slave mentality" of Indian women (bharatiya nari - read Bengali women) encapsulates a middle-class, educated and "liberated" Bengali woman's awareness of her own dignity and rights, her sense of self-worth, her refusal to accept domination or discrimination in any form from her husband and her vehement rejection of the idea of husband as "Lord" and "Master". However, the author contrives to make her utterances ring hollow, voiced as they are against a husband who is, as Indu herself admits, the most considerate and "obedient" husband one could find. Subverting the equation of family power dynamics and portraying Indu as self-willed, proud and temperamentally volatile, the author has perhaps sought to indicate the unnatural balance of conjugal relationship that in the end becomes instrumental in destroying the family unit and conjugal love. Juxtaposed against Indumati's over emphasized self-esteem is Bimala's "quiet", enduring, dutiful, and unshakeable loyalty towards her husband and his family - the essence of womanly virtues as projected, patronised and eulogized by a society rooted in a patriarchal, feudal value system. His wish is her will...yet, Indu, who has recoiled in disgust at Bimala's admission of 'servility' to her husband is surprised to find evidences of Gaganbabu's and Ambikababu's submission to their wives' will. Sharat Chandra here indicates that Indu's pride in education and contempt for "ignorant" women like Bimala have blinded her to the possibility of a conjugal love and bliss that is experienced in the submersion of one's self in the other or the absolute, unconditional surrender that true love entails. Ironically, for Indu, who has married the man she had fallen in love with, the idiom of love and its expression has been confined to an assertion of self-will -- a selfishness that hardens her pride to a point where she abandons Narendra and leaves for her father's place. Indu's protests epitomize the shahure (urban) woman's superficial and acquired ideas about liberty. It is only through her baptism in tears and repentance, her recognition of her "true place" beside Naren -- re-inforced by her self-realisation, which is no less aided by her brother, relatives and Bimala (the agencies of society that perpetuate the feudal values) that she is 'redeemed'. Reminiscent of the return of the prodigal, Indu, a destitute in love, has to shed her material possessions (wealth has been her pride and illusory power) to reclaim her position as the loving wife. In other words, the fear of isolation and homelessness quenches her sense of superficial independence to bring her back to the fold or safe haven of feudal values. The author posits a picture of dignity through sacrifice and surrender of ego (which forms the essence of Indian womanhood) while retaining one's individuality and clarity of vision - a positive 
self esteem that need not negate another person to gain stature - as perhaps an alternative brand of national (read Bengali) feminism that could emerge in the backdrop of the complex, stratified Indian society. Not imposed from above or outside and springing from the roots of a national cultural heritage that was ancient yet dynamic (and ever changing) - such a feminism could perhaps, in Sharat Chandra's vision, begin to form an original, indigenous, parallel strand that could grow symbiotically with the changing patterns of life-pace and ideologies and yet not destroy or jeopardize the firm foundation of positive faith in liberal humanism or the indigenous cultural strongholds of the nation. What problematizes this concept of feminism is its inability to take cognizance of the feminist debate that has shaken the foundation of the family as an institution - the politics of personal and familial relationships. Sharat Chandra's vision of a family founded on mutual faith and conjugal bliss precludes the possibility of a power play operating within the family fold. Hence Naren's sometimes unbearably stubborn silence is read as admirable fortitude and patience while Indu's more volatile temper and frequent display of ire earns her the reputation of a shrew. Indu is a largely misunderstood personality as even the author has undermined her forthrightness and capacity for genuine love to foreground her shrewish temper and emasculating behaviour. The author in fact reconfirms here the patriarchal society's aversion for and denouncement of an ambitious or 'money minded' woman, who is a shrew to as well.

Turning our enquiry upon Sharat Chandra Chattopadhyay's Grihadaha, we encounter the soul-shaking picture of desolation, hopelessness and isolation of a woman who despite her city-bred ideas of liberty and women's rights, cannot avoid the pitfall of social stigma or terrible self-conflict and scorching shame as she is torn between her love for her husband Mahim (who is her choice and preference and whose love for her is quiet and unassuming) and the complex love-hate-fear-thrill turbulence aroused in her when confronted with the naked, mindless passion of Suresh's uncontrolled love for her. It is noteworthy that Sharat Chandra had never gauged either in his fictional representation or otherwise a woman's chastity or fidelity to her husband - satitwa - in terms of the social bondage that the institution of marriage signified for a woman. For him, a woman's integrity of character could not be undermined by the superficial behaviourial interpretations based on the normative code of conducts laid down by society. In this sense his women protagonists or his perception of women as such was "modern". 9 Yet his women, be it Abhaya (Srikanta), Kamal (Shesh Prashna) or Achala (Grihadaha), meet with fates that are demoralizing and frightening. Their independence and protests achieve very little and culminate in helplessness and isolation thus preventing them from emerging as role models for other women. In Grihadaha Achala refused to be forced into a marriage of convenience with Suresh and resisted compromise, but her victory in marrying a person of her own choice is short lived. Faced with the harsh reality of living in a dilapidated hut devoid of all amenities of city life she has been used to since childhood, confronted with the unwelcoming hostility of the palli samaj (village community), Achala's vision of a blissful wedded life and rosy future gradually loses colour. The tenuous emotional bondage with Mahim, (who is a contained, stoic man not given to expressive professions of love), is further strained by the ugly suspicion of an illicit relationship between Mrinal and Mahim (who are sort of cater cousins) on the one hand and the sudden, uninvited appearance of Suresh at the threshold of their home (a symbolic act of intrusion into their private space) on the other. The literal fire that demolishes Achala's home is also the symbolic fire of suspicion and guilt that devastates her married life (dampatya jiban). Angered at Mahim's unperturbed calm, which she interpretes as callous indifference, Achala commits the ultimate crime of violation of faith and the sacred marriage vows by uttering a fateful denial of her love for her husband. Achala's uncharacteristic outburst draws in itself all the indignation, insult and pain a woman feels at the discovery of an imagined evidence of her husband's betrayal. Mahim fails to understand her vicious need to hurt her object of love and rejects her spontaneous offer of selling her ornaments in order to set up another home. Though Achala proves her true allegiance by insisting upon staying by her husband's side and sharing his grief, her concerned overtures are spurned sternly by Mahim who decides that it is best for her to return to her parental abode. Here Achala emerges as the true soul mate and life partner whose worth goes unappreciated. Mahim's unintentional (the narrative gives him the benefit of doubt) cruelty and devaluing of her love breaks Achala's heart but hardens her resolve not to betray further weakness of affection before the stone hearted stranger whom she no longer recognizes as the man she loves.

The stranglehold of feudal values that gripped the psyche of the so-called Bengali elite can be easily understood through the typical reaction of Achala's father (a member of the 'enlightened' and 'educated' Brahmo Samaj) at her return in disgrace from Mahim's house accompanied by Suresh. A father who had once had no compunction in trying to force his daughter's hand in marriage to Suresh (who is wealthy and generous) now casts his suspicion at his daughter for having somehow violated the sacred tenets of marital bondage. He does not mince words in showing his disapproval of his once beloved daughter and does not care to give her the benefit of doubt. The once amiable and indulgent father had suddenly assumed the mantle of a patriarch who felt the need to discipline his headstrong and errant daughter. A professed liberal who had contrived to thrust Achala at Suresh, having discovered the latter's attraction towards her, had now blithely shifted the blame on the erring female and assumed the role of a guardian of societal laws and a custodian of family name and 'honour'. Again, 
despite Suresh's overwhelming love for Achala, he could insult her by comparing her to Mrinal, eulogizing the latter's unselfish sacrifice, devotion, material indifference (boiragya), dutifulness, endurance, loving care and above all fidelity (Satitwa).

Achala's 'satitwa' is awakened with a vengeance just when she had resigned herself to lead an isolated if barren life and bear her grief in the privacy of her father's house and learned to accept her father's suspicions regarding her virtue. Fate however brought her fatally ill husband back to her whom she nursed back to health. She had just begun to reconstruct her dreams of a future with him when another storm of Suresh's irrational love swept her away from the safe shores of respectable matrimony to a life of self-torture, indignity and utter desolation. She found her own space and a temporary abode in Dihiri, away from Bengali society and its strictures. Despite her physical ravishment by an obsessed Suresh, Achala remained loyal in her mind and soul to her husband's memories. Here lay the challenge to the claims of a marital fidelity that demanded physical chastity as a testimony to a woman's undying love. Achala remained unsullied in spirit despite her 'fall' in terms of social codes. Ironically, Achala's liberal upbringing and education according to Bramho tenets had not equipped her to resist the onslaught of age-old social beliefs that took her mind and soul by storm.

Achala's unconventional thoughts and action may be lauded in the context of the conservative Bengali society which is the backdrop of the novel, but her rebellion was not a conscious rejection or challenge of social norms that she found meaningless. Her jealous anger at being compared to Mrinal is born out of her own sense of inadequacy as the ideal Bengali housewife. She craves for satitwa and social condonement and approval for her actions as much as Mrinal or Bimala. Suresh's Pishima's (aunt) blessings ring sweetly in her ears --blessings that contain the essence of a woman's existence (as perceived by society and deeply ingrained in the psyche of women who have for centuries unconsciously internalized patriarchal values and social expectations) -to be a loyal and loving wife and mother, a nurturer and giver. So when Achala refuses to keep fast for Suresh's well being, it is not because she condemns such rituals but because she cannot betray her fidelity to Mahim. The guilt and shame that engulfs her does not allow her to acknowledge her natural response to Suresh's steady devotion. A liberal upbringing has after all not been able to erase the pull of the collective will on the unconscious or the belief that the well spring of cultural values resides 'naturally' in women. The paradox of woman's role as the culture bearer - a role that condenses in itself the dual burden and pain of imposed responsibilities - has circumscribed women in the name of glorified traditions, curbed the freedom of her self and obstructed her self- realization. So Achala's apparent rebellion ends in a self-imposed exile, which is her way of repenting for the crime she thinks she has committed in violating the sanctity of her marriage vows. At the novel's denouement we find Achala imploring Mahim's advice after Suresh's death to decide the course of her future life, which would be confinement and celibacy in a Stree Ashram - a women's convent - and a life spent in seeking peace of mind. With all his stoicism, generosity and understanding of Achala's predicament, Mahim, like the epic hero Lord Rama, is unable to provide solace or refuge to a wife whose reputation and 'honour' has been sullied irredeemably in the eyes of the society.

\section{Conclusion}

In the final analysis it may be concluded that Sharat Chandra Chattopadhyay's vision of woman's liberty and her struggles for attaining selfhood was filtered through his consciousness of his own cultural, social and literary heritage in relation to the new idioms that were relentlessly influencing and shaping a creative artist's imagination in that day and age. Despite his exceptional empathy with women, his perception of an 'ideal' woman was still shaped and influenced by the prevailing feudal, patriarchal conception of woman as naturally the giver and the nurturer. While denouncing the double standards exercised by society in devaluing women, he also felt the need to represent the failure of an acquired western brand of feminism that threatened the dissolution of the family unit or the social structures, which were invested with so much of national emotions and which formed the very basis of Indian culture and tradition. In challenging existing social biases, Sharat Chandra Chattopadhyay's women protagonists however could not address entrenched patriarchal values within the social edifice. However, though they failed to emerge as role models for other women, they could at least register strong statements of individual protest as admirably unconventional and forthright women who had the courage to think and act differently in an age and society that was conservative and delimiting.

Notes and References

[1]. Mazumdar, Swapan. "Cultural Relativism in a Colonial Context", Comparative Literature: Indian Dimensions, Papyrus: Calcutta, 1987, p.75

ibid, p.77

[3]. ibid

[4]. ibid, p.79

[5]. Pandit, Maya. "Towards Indian Feminist Literary Criticism", Indian Literary Criticism in English, ed. P.K.Rajan, Rawat Publications: New Delhi, 2004. p.307

[6]. Gupta, R.K. 'Feminism and Modern Indian Literature', Indian Literature, 157 (Sept/Oct)1993

[7]. Mazumdar, Swapan, ibid. p.81 
[8]. Chattopadhyay, Sharat Chandra. "Narir Mulya”, Sharat Sahitya Samagra, Vols.I and II, Anand Publishers Private Ltd., Calcutta, 1986. p. 1947

[9]. ibid. p. 1951

[10]. Bandopadhyay, Jayanta. Sharat Shahitye Byakti O Samaj, Karuna Publications, Kolkata: 1406 (Bengali year), p.15

[11]. Radical Feminism sees men's domination of women as a result of the system of patriarchy, which is independent of all other social structures. Radical feminists like Shulamith Firestone deconstructed the family as a social institution and fore grounded the personal vs political debate, emphasizing the need to view the family as a site of power play replicating social hierarchies and perpetuating the subjugation of women.

\section{Primary Source}

Sharat Chandra Chattopadhyay's Sharat Shahitya Samagra Vols. I \& II Edited .by Sukumar Sen Anand Publishers Private Ltd., Calcutta, 1986. 